\title{
Investigation of Microstructure, Phases and Micro-Hardness of Molybdenum Coatings Deposited by Flame Wire Spray on Steel
}

\author{
Mokhtar Djendel ${ }^{\mathrm{a}, \mathrm{b} *}$, \\ Omar Allaoui ${ }^{b}$, Rabah Boubaaya ${ }^{a, b}$, \\ Samir Benaniba ${ }^{a}$ and Mourad Maazouz ${ }^{\text {b,c }}$ \\ ${ }^{a}$ Département S.T, Faculté des Sciences et de la Technologie \\ Université Mohamed El Bachir El Ibrahimi de Bordj Bou Arreridj \\ Algeria \\ ${ }^{b}$ Laboratoire de Génie des procédés \\ Université Amar Telidji-Laghouat \\ Algeria \\ 'Département de Génie Mécanique \\ Faculté de Technologies, Université de M'sila \\ Algeria
}

Received 12.02.2020, received in revised form 20.03.2020, accepted 09.04.2020

Abstract. Coating deposition on many industrial components with good microstructural, mechanical properties and better wear resistance is always a challenge for the thermal spray community. A number of thermal spray methods are used to develop such promising coatings for many industrial applications; viz. arc spray, flame spray, plasma, and HVOF. All these processes have their own limitations to achieve porous free, very dense, high performance wear resistant coatings.

In this study, an attempt has been made to overcome this limitation. Molybdenum coatings were deposited on steel substrates using Wire flame. As-sprayed coatings were analyzed for phase using $\mathrm{x}$-ray diffraction (XRD), and for microstructural using scanning electron microscopy (SEM), also the micro-hardness of coatings are measured. Results show that the coatings have good performance in terms of microstructural, mechanical properties.

Keywords: Flame wire spraying, Coating, microstructure, micro-hardness, XRD, SEM.

Citation: Djendel M., Allaoui O., Boubaaya R., Benaniba S., Maazouz M. Investigation of microstructure, phases and microhardness of molybdenum coatings deposited by flame wire spray on steel, J. Sib. Fed. Univ. Eng. \& Technol., 2020, 13(4), 495-501. DOI: 10.17516/1999-494X-0240

(C) Siberian Federal University. All rights reserved

This work is licensed under a Creative Commons Attribution-Non Commercial 4.0 International License (CC BY-NC 4.0).

* Corresponding author E-mail address: djendelm@gmail.com 


\title{
Исследование микроструктуры, этапов
}

\section{и микротвердости покрытий из молибдена, \\ нанесенных спреем из вспененного материала на сталь}

\author{
Мохтар Джендель ${ }^{\mathbf{a}, \tilde{\sigma}}$, Омар Аллауи \\ Рабах Бубаая, ${ }^{\mathrm{a}, \boldsymbol{0}}$ Самир Бенаниба ${ }^{\mathrm{a}}$, Мурад Маазуз \\ ${ }^{a}$ Университет Мухаммеда Эль Бачира \\ Эль Ибрахими Бордж Бу Бу Арреридж \\ Алжир \\ ${ }^{6}$ Университет Лагуата \\ Алюжир \\ ${ }^{\circ}$ Университет М'Сила \\ Алжир
}

Аннотация. Осаждение покрытий на многих промышленных компонентах с хорошими микроструктурными, механическими свойствами и лучшей износостойкостью всегда является проблемой для сообщества термических распылителей. Ряд методов термического напыления был использован для разработки таких перспективных покрытий для многих промышленных применений; а именно дуги, пламя, плазма и HVOF. Все эти процессы имеют свои ограничения для получения пористых свободных, очень плотных, высокоэффективных износостойких покрытий.

В этом исследовании была сделана попытка преодолеть это ограничение. Молибденовые покрытия наносили на стальные подложки с использованием проволочного пламени. Покрытия после напыления анализировали на фазу с использованием дифракции рентгеновских лучей (XRD), а для микроструктуры с использованием сканирующей электронной микроскопии (SEM) также измеряли микротвердость покрытий. Результаты показывают, что покрытия имеют хорошие характеристики с точки зрения микроструктурных, механических и износостойких свойств.

Ключевые слова: распыление пламенной проволоки, покрытие, микроструктура, микротвердость, XRD, SEM.

Цитирование: Джендель, М. Исследование микроструктуры, этапов и микротвердости покрытий из молибдена, нанесенных спреем из вспененного материала на сталь / М. Джендель, О. Аллауи, Р. Бубаая, С. Бенаниба, М. Маазуз // Журн. Сиб. федер. ун-та. Техника и технологии, 2020. 13(4). С. 495-501. DOI: 10.17516/1999-494X-0240

\section{Introduction}

The thermal spray method is a technique-using spray gun to fill the melted particles on a previously prepared surface, layers of metallic or nonmetallic materials. followed by fast cooling process and solidification [1]. The Thermal spray technology has been used intensively as a heat-resistant coating for space industries, boiler components, offshore rigs and equipment in the oil and gas industries. There are several types of thermal spray commonly used such as High Velocity Oxygen Fuel (HVOF) and Electric Arc Spray and Plasma spray.

Nevertheless, Combustion Flame Spray is classically used in the restoration of the worn mechanical elements submitted to frictions in service to reach again the correct original thickness after a large technical life [2]. 
A projected coating is of high quality when good cohesion of the deposit is obtained as well as high adherence of the coating on its substrate. If the adherence proves to be insufficient bonds coat are commonly used among which molybdenum or alloys of the type NiAl [3]. Flame spray is a widely used coating deposition method in the broad category of thermal spraying, in which molybdenum wire is melted through a high-temperature flame and compressed air breaks the molten wire into several small droplets, resulting in splats formation and that builds up a coating $[4,5]$.

In this study, the influence of the thickness of this bond coat on the adherence of the final deposit is investigated. In this goal, two types of composite systems were prepared: (A) a single layer of Mo bond coat/substrate $42 \mathrm{CrMo} 4$ and (B) coating by flame wire using steel (Sprasteel LS) as an undercoat layer (Tab.III.2), and molybdenum as bond coat. The purpose of the composite systems was to investigate qualitatively the role of the bond coat on the adherence of the deposit. In addition, a scanning electron microscope (SEM) was used to view the microstructure of the coatings. The crystalline structure of the coatings was investigated by X-ray diffraction (XRD).

\section{Experimental methods}

\subsection{Materials and coating deposition}

The samples we used for our tests come from round bars steel substrate it was $42 \mathrm{CrMo} 4$ of $60 \mathrm{~mm}$ in diameter, and the coating was a steel (Sprasteel LS). Their chemical compositions are presented in Table 1, and Table 2. Molybdenum (Mo) was used for the bond coat. Steel (Sprasteel LS) and Mo were deposited as a wire using a standard flame-wire "MARK 60".

Prior to the deposition, the substrates were cleaned, degreased, grit blasted with corundum particles and finally subjected to ultrasonic cleaning using acetone.

The fabrication parameters of the bond coating and the top coating are shown in Table 3, which were recommended by the manufacturer.

\subsection{Characterization and analysis techniques}

The microstructure of the composite coating was examined by using a scanning electron microscopy (SEM).The phases present in the coatings were identified using an X-ray diffraction (XRD).

Measurements of the micro-hardness of the deposits have been made on surfaces of polished sections. Micro-hardness testing was performed on the samples with a Vickers micro-hardness tester

Table 1. Chemical composition of the steel to be coated (\%)

\begin{tabular}{|c|c|c|c|c|c|c|}
\hline $\mathrm{C}$ & $\mathrm{Cr}$ & $\mathrm{Mo}$ & $\mathrm{Mn}$ & $\mathrm{Si}$ & $\mathrm{P}$ & $\mathrm{S}$ \\
\hline $0.38 / 0.45$ & $0.90 / 1.20$ & $0.15 / 030$ & $0.60 / 0.90$ & $0.40 \max$ & $0.035 \max$ & $0.035 \max$ \\
\hline
\end{tabular}

Table 2. Chemical composition of the steel (Sprasteel LS) to be coated

\begin{tabular}{|c|c|c|c|c|c|}
\hline $\mathrm{C}$ & $\mathrm{Cr}$ & $\mathrm{Mo}$ & $\mathrm{Mn}$ & $\mathrm{Ni}$ & Breaking load \\
\hline $0.04 \%$ & $1.5 \%$ & $1.5 \%$ & $2 \%$ & $4 \%$ & $2300 \mathrm{Kg} / \mathrm{Cm}^{2}$ \\
\hline
\end{tabular}


Table 3. Thermal spray conditions

\begin{tabular}{|l|c|c|}
\hline & Wire of Steel (Sprasteel LS) & Molybdenum \\
\hline Spraying air pressure & $4.6 \times 105 \mathrm{~Pa}$ & $3.8 \times 105 \mathrm{~Pa}$ \\
\hline Acetylene pressure & & $1.2 \times 105 \mathrm{~Pa}$ \\
\hline Oxygen pressure & $4 \times 105 \mathrm{~Pa}$ & $4 \times 105 \mathrm{~Pa}$ \\
\hline Propane pressure & $3 \times 105 \mathrm{~Pa}$ & $0.02 \mathrm{~m} / \mathrm{s}$ \\
\hline Speed of wire moving & $0.02 \mathrm{~m} / \mathrm{s}$ & $150 \mathrm{~mm}$ \\
\hline Spaying distance & $150 \mathrm{~mm}$ & $3 \mathrm{~mm}$ \\
\hline Wire diameter & $3 \mathrm{~mm}$ & $90^{\circ}$ \\
\hline Spray angle & $90^{\circ}$ & \\
\hline
\end{tabular}

(Zwick ZHV10) using a load of 200 g. Twelve measurements are performed to evaluate an average value and a standard deviation of this parameter.

\section{Results and discussion}

\subsection{Microstructural investigation}

To better understand microstructural variations, the samples were characterized by scanning electron microscopy (SEM). Coating presents a classical layered morphology, characteristic of the thermal spray process [6, 7]. Typical cross-section morphology of the composite systems A (Mo bond coat $/ 42 \mathrm{CrMo} 4)$ \& B (steel (Sprasteel LS) layer/Mo/42CrMo4) are presented in (Fig. 1). The deposit formed coating using these two systems: (A) \& (B) coating has pores. where their sizes are becoming larger near the interface. In addition, these micrographs show that the bonding of molybdenum on steel is not perfect because there is a vacuum between the two materials. These pores are due to partial filling and trapped gases. The size of the particles and their speed have an important influence on the density of the deposits.

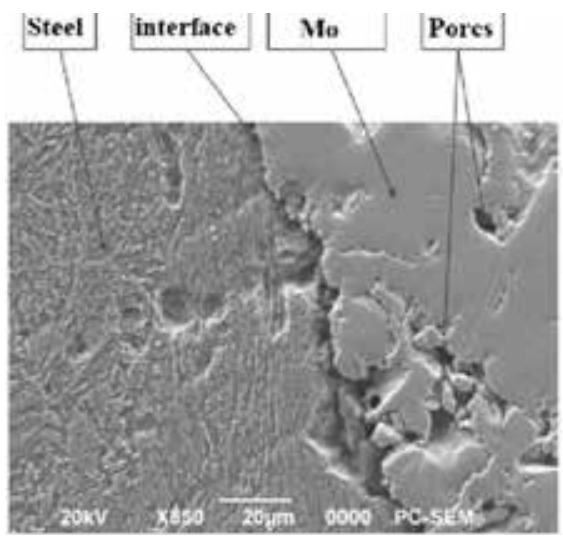

A

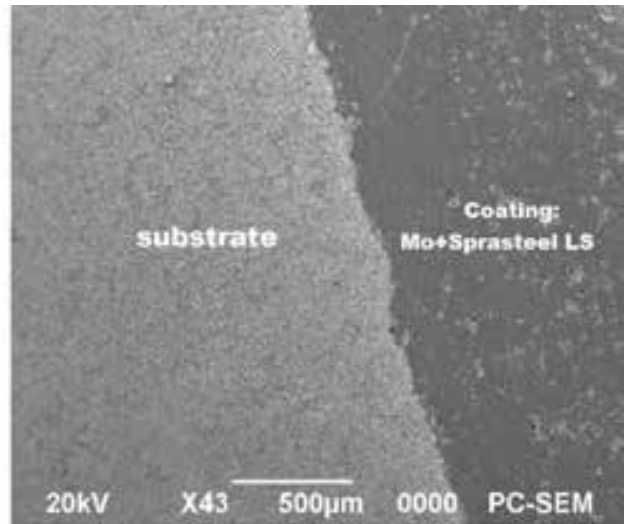

B

Fig. 1. SEM micrographs: Typical cross-section morphology of the composite systems: A (Mo bond coat/42CrMo4) \& B (Sprasteel LS layer/Mo/42CrMo4) 
The sprayed deposits exhibit: poor adhesion and partially recorded cohesion between the particles on the one hand, and poor adhesion of the particles to the substrate on the other hand. Publications claim that these defects are due to poor crushing of the particles during impact (spray parameters not respected) and to poor preparation of the surface to be coated [8].

\subsection{Characterization by X-ray diffraction (XRD)}

The diffraction spectrum obtained is presented in Fig. 2. X-ray diffraction is performed on the surface of the deposited molybdenum. Note that molybdenum has a C.C. structure. This spectrum clearly reveals the peaks of molybdenum, which are: (110), (200), (211) and (220). On the other hand, the other peaks, which are not indexed, can only be the peaks of the oxides also; their intensities are not significant compared to the peaks of molybdenum, which reflects the presence of a small amount of these oxides.

In addition, the spectrum of X-ray diffraction analysis of composite systems B (Sprasteel LS layer/Mo/42CrMo4) is very similar to that of case of the composite system A. This result confirms the deposition of molybdenum.

\subsection{Micro-hardness}

The curve of the hardness profile of the sample coated with the composite systems A (Mo bond coat/42CrMo4) \& B (steel (Sprasteel LS) layer/Mo/42CrMo4) are presented in Fig. 3. In the system (A), there are two pseudo-levels: The first stage corresponds to a high hardness $(540 \mathrm{Hv}-$ $480 \mathrm{Hv}$ ) and corresponds to the deposit of molybdenum, which has a high hardness. The second

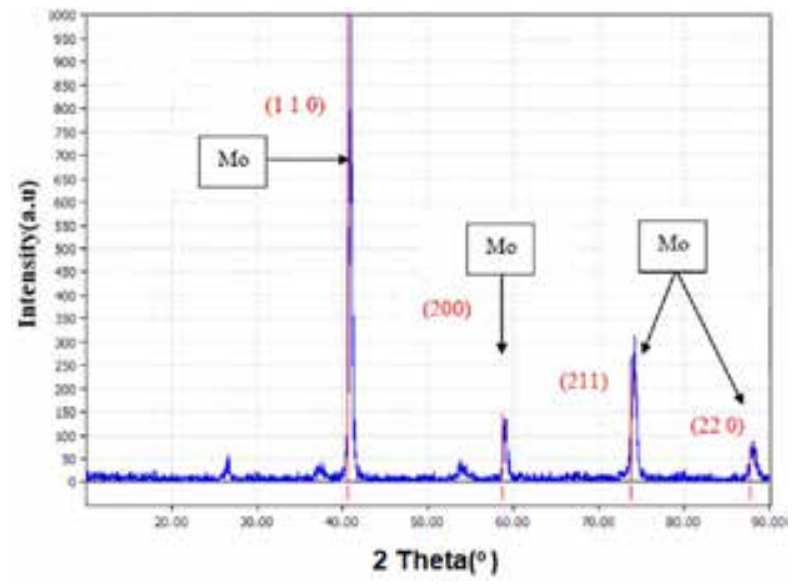

Fig. 2. XRD diffractogramme of: the composite systems: A (Mo bond coat/42CrMo4) \& B (Sprasteel LS layer/ $\mathrm{Mo} / 42 \mathrm{CrMo} 4)$

stage is limited in the following interval $(350 \mathrm{Hv}-240 \mathrm{Hv})$. This last stage is characterized by a slight decrease in hardness to the heart of steel. Between these two stages, there is a hardness drop of $480 \mathrm{Hv}$ to $350 \mathrm{Hv}$.

For the micro-hardness of composite systems B (Sprasteel LS layer/Mo/42CrMo4), we notice the same variation in micro-hardness as shown in Fig. 2. but with slightly higher micro-hardness 
Table 4. Change in micro-hardness depending on the thicknesses of the carburizing layer

\begin{tabular}{|c|c|c|}
\hline & \multicolumn{2}{|c|}{ Micro-hardness (HV) of composite systems } \\
\hline Area layer & A & B \\
& Mo bond coat/42CrMo4 & Sprasteel LS layer/Mo/42CrMo4 \\
\hline Coating deposit & $540 \mathrm{Hv}$ & $735 \mathrm{Hv}$ \\
\hline Near the interface & 344 to $495 \mathrm{Hv}$ & 370 to $660 \mathrm{Hv}$ \\
\hline
\end{tabular}

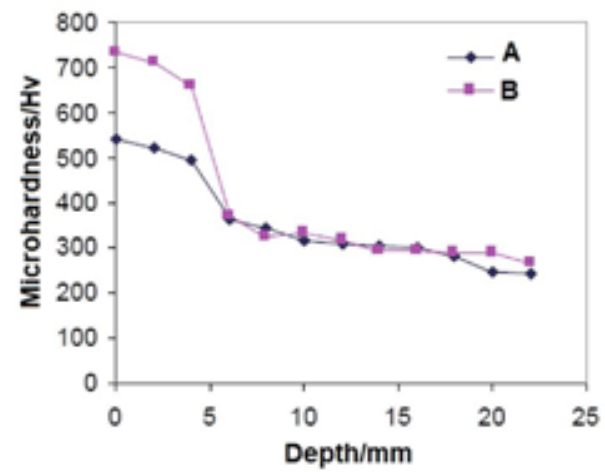

Fig. 3. Micro-hardness (HV) of composite systems A (Mo bond coat/42CrMo4) \& B (Sprasteel LS layer/ $\mathrm{Mo} / 42 \mathrm{CrMo} 4)$

values compared to the previous case. In the latter case, the hardness of the deposited metal is higher $(735 \mathrm{Hv})$, which shows the difference between the two deposits systems. Consequently, the deposition of molybdenum by the use of a bonding layer of steel gives a harder deposition [8].

\section{Cownclusion}

Based on the obtained results in the present investigation, the following conclusions can be written:

1) It has been shown that during the process of fame wire spray, a slight local diffusion of molybdenum has occurred with steel. This diffusion is justified by the decrease in the concentration of molybdenum from the surface to a certain depth. The temperature is the most important parameter in this coating process since this local diffusion is above all a thermally activated phenomenon.

2) SEM observation showed the presence of pores inside deposited molybdenum.

3) The micro-hardness of Mo coating deposited in the present study is higher than that of the substrate. The mechanical properties have improved a lot, in the deposition area, at the interface and near the interface where $312 \mathrm{Hv}$ (composite system A) and $315 \mathrm{Hv}$ (composite system B) were recorded.

\section{References}

[1] Peyre J.P., Tournier C. Choix des traitements thermiques superficiels, éd. CETIM. 1985.

[2] Thorpe M.L. Thermal spray industry in transition (industry overview). Adv. Mater. 1993. Proc. 143 (5), 50. 
[3] Barbezat G. Application of thermal spraying in the automobile industry. Surf. Coat. Technol., 2006, 201, 2028-2031.

[4] Davis J.R. Handbook of Thermal Spray Technology. 2004. ASM International.

[5] Pawlowski L. The Science and Engineering of Thermal Spray Coatings. England: John Wiley \& Sons, Ltd. 2008.

[6] Zhao L. and Lugscheider E. Influence of the spraying processes on the properties of 316L stainless steel coatings, 2002, 162, 6-10.

[7] Saini H., Singh Er. Pardeep. Microstructural characterization thermal spray coating on stainless steel AISI 316L. International Journal of Advance Research, Ideas, and Innovations in Technology, 2017, 3.

[8] Mohand Amokrane Hanlin L. et Ghislain M. Bases théoriques de la projection thermique, LERMPS, M'sila. 2004.

[9] Bradai Nedjemeddine Bounar, Abderrahim Benabbas, Abdelaziz Ati. Study of microstructure, phases and micro-hardness of metallic coatings deposited by flame thermal spray. Journal of Materials Processing Technology, 2008, 200 (1-3), 410-415. 